\title{
Personal and Emotional Factors in the Labour Integration of University Graduates in the Field of Education. Implications for University Teaching.
}

Juan L. Castejón ${ }^{\star 1}$, Raquel Gilar ${ }^{2}$ and Pablo Miñano ${ }^{3}$

$\approx \quad$ The main aim of this paper is to analyse the role of intellectual, personal and emotional competencies as well as technical knowledge - academic achievement - in the employment of university graduates, with the purpose of incorporating these competencies into training programmes developed within the European Framework of Higher Education. This study is based on an initial sample of 118 university graduates in the field of education. We have gathered information about academic achievement and the intellectual, personal and emotional traits of this sample. From these data, and given the importance of non-intellectual aspects of intelligence associated with professional success, the specific contribution -incremental validity - of personal and emotional intelligence in explaining the employment - labour integration - of university graduates in the field of education is studied. From this point onwards, we attempt to identify the key socio-emotional competencies in the field of education in order to establish the implications of including this type of skills in university training programmes within the European Higher Education Area.

Key words: Emotional intelligence, Labour integration, Personality, University education of teachers

$1 \quad{ }^{\star}$ Corresponding author: University of Alicante- Spain, Department of Developmental Psychology and Didactics; Carretera San Vicente s/n; o3080 - Alicante, Spain.

jl.castejon@ua.es

2 University of Alicante- Spain

3 University of Alicante- Spain 


\section{Introduction}

The main objective of this research project is to analyse the role that intellectual, personal and emotional traits play in predicting and explaining integration into the labour market of university graduates from Departments of Education, while also establishing the implications of including personal and emotional competencies in university academic curricula (Ayers \& Stone, 1999; Fallows \& Steven, 2000; Hettich, 2000; Jaeger, 2003). The personal and socio-emotional factors included in this study are very similar to several of the generic competencies established within the European Higher Education Area (European Education Council, 2006; Gonzalez \& Wagenaar, 2003).

Traditionally, academic intelligence is associated with general or analytical intelligence as defined in psychometric terms, such as IQ (Sternberg, 2003; Sternberg, Castejón, Prieto, Hautamäki \& Grigorenko, 2001; Sternberg, Prieto \& Castejón, 2000). Meanwhile, social intelligence is a broad construct with less easily defined boundaries, and which in scientific literature is in some cases linked to emotional intelligence (Bar-On, 200o; Goleman, 1998) and in others to practical intelligence (Hendlund \& Sternberg, 200o). Likewise, the definition of emotional intelligence includes two different conceptions (Bar-On, 2000; Mayer, Roberts \& Barsade, 2008). One broad conceptualisation considers emotional intelligence as a combination of attributes that are intimately tied to personality but different from IQ and related to competencies underlying academic and professional performance (Bar-On, 200o; Goleman, 1995, 1998). Another more restrictive conceptualisation considers it as the ability to perceive and understand emotion-related information (Mayer, Caruso \& Salovey, 200o).

Skills inherent to socioemotional intelligence, once correlated to performance in the professional realm, have been considered as competency models (Boyatzis, 1999; Boyatzis, Goleman \& Rhee, 2000). In particular, mixed models of emotional intelligence bring together broad competencies of a socioemotional nature (Mayer, Salovey \& Caruso, 200ob). Furthermore, most professional competencies identified as key competencies for professional performance comprise, or are closely related to, aspects under study in the field of emotional intelligence.

Research on emotional intelligence (Bar-On, 2000; Goleman, 1997, 2001; Mayer, Roberts \& Barsade, 2008) traditionally emphasises the value of non-intellectual factors in predicting/explaining academic 
and professional achievement. Some authors even pose the hypothesis that individual academic qualifications are less important than personal factors as grades are a condition common to a large group, whilst what increases opportunities for employment is a compendium of attitude-based competencies and social skills concerning work (Mora, 1997; Planas et al., 2000), in addition to continued training. In this regard, García-Aracil and Van der Velden (2008) find that graduates with more professional competencies have higher incomes and greater levels of satisfaction with their employment.

Cognitive abilities are especially important in the workplace, particularly when one's job is more complex (Gottfredson, 2003), whereas emotional competencies are considered critical to effective performance in most types of jobs (Cherniss, 2000), as well as in relation to labour integration and employability (Palací \& Topa, 2002; Palací \& Moriano, 2003).

Socioemotional competencies are highly valued in the labour market. Most jobs do not merely require technical knowledge and skills, but also a certain level of socioemotional competencies. Cherniss (2000) points out that a major part of investment by American companies in training targets social and emotional abilities. A national survey carried out with American employers concluded that six of seven competencies key to professional success are inherent to emotional intelligence (Ayers \& Stone, 1999; Goleman, 1998). Nevertheless, most universities fail to include these competencies in their syllabi (Boyatzis et al., 1995; Echeverría, 2002).

Although these competencies do not exclusively predict or explain professional performance (Schmidt \& Hunter, 1998), emotional competencies seem to have an explanatory power that goes beyond other variables (Goleman, 1998). These competencies affect important aspects of one's professional career, such as labour integration or employability (Fallows \& Steven, 2000; Hettich, 2000).

Despite the importance attributed to some inherently non-intellectual aspects, such as personality and emotional intelligence, in academic and professional achievement as well as professional development in general (Coté \& Miners, 2006; Dulewicz, Higgs \& Slaski, 2003; Lopes et al., 2006; Pérez \& Castejón, 2007), greater empirical evidence is required regarding this relationship, as the influence of these variables is not always evident (Barchard, 2003; Brackett \& Mayer, 2003; Zeidner, Mathews \& Roberts, 2004). Likewise, well-designed studies that control variables traditionally considered to be important - such 
as variables related to personality, intellect, and technical knowledge (Davies, Stankov \& Roberts, 1998; Sternberg, 2003) - are necessary to detect the contribution of these factors to the labour integration of university graduates. Therefore, the incremental validity of personal and emotional factors must be defined in order to predict a given criteria - in this case, labour integration - beyond the contribution made by measurements of general intelligence and acquired technical knowhow (Amelang \& Steinmayer, 2006; Bastian, Burns \& Nettelbeck, 2005; Brackett \& Mayer, 2003; Van-der-Zee, Thijs \& Schakel, 2002).

In addition, it is necessary to establish the general or specific nature of different aspects of non-academic intelligence for the purpose of identifying either general factors shared across different professional fields or specific components of personality and emotional intelligence associated with achievement within each profession (Boyatzis, 2008; Boyatzis, Goleman \& Rhee, 2000).

In the field of teaching, a positive relationship is found between emotional intelligence and teachers' personal adjustment and wellbeing (Palomera, Fernández-Berrocal \& Brackett, 2008). Studies analysing the relationship between emotional intelligence and burnout in secondary level education teachers (Chan, 2006) show how burnout negatively influences teacher wellbeing (Vanderberghe \& Huberman, 1999) and teacher-student interpersonal relationships (Yoon, 2002).

Jennings and Greenberg (2009), as well as Sutton and Wheatly (2003), reveal the close relationship between a teacher's socioemotional competencies and effectiveness/quality during teaching-learning processes, as well as the development of students' prosocial behaviour in the classroom. Di Fabio and Pazazzeschi (2008) evaluate the relationship between emotional intelligence and self-efficacy in a sample of Italian professors. Chan (2008) carries out a similar study to consider the relationships between the emotional intelligence, self-efficacy and ability to cope of teachers in Hong Kong. In Spain, the study on perceived emotional intelligence and life satisfaction among university teachers carried out by Landa, López-Zafra, Martínez, and Pulido (2006) is worth mentioning.

Weare and Grey (2003) conclude with recommendations for teacher-training organisations to explicitly develop personal and socioemotional competencies, based on the premises that it is impossible either to teach a competency one does not possess or to offer quality teaching in the absence of personal wellbeing.

Given the above, the specific objectives of this project are: a) 
to develop a predictive model that includes traits related to intelligence, personality, emotional intelligence and knowledge/academic achievement as explanatory variables for the labour integration of university graduates from Departments of Education; b) to evaluate the predictive value of non-intellectual factors, personality and emotional intelligence in predicting labour integration once the effect of intellectual variables, such as intelligence and academic performance, are controlled; and c) to establish implications for developing personal and emotional competencies within university syllabi in the European Higher Education Area.

\section{Method}

\section{Participants}

The initial sample consisted of 118 undergraduates studying for a degree (Teaching in Preschool, Primary and Secondary Education) at the Department of Education of the University of Alicante, Spain. The students ranged in age from 20 to 35 , with a mean age of 22.61 years. Males represented $26.2 \%$ and females $73.8 \%$ of the sample.

\section{Instruments}

The following instruments were used to assess the variables analysed in this study.

The test of $g$ factor Scale 3 by Cattell and Cattell, for group-administered testing, composed of 4 subtests which include incomplete and progressive series for testing cognitive abilities of identification, perceived similarities, seriation, classification, matrices and comparisons, was used to obtain the IQs of all the participants sampled. Gfactor saturation was high, around o.9o.

The NEO Five-Factor Inventory (NEO-FFI) by Costa and McCrae (1992), Spanish language adaptation by TEA Ediciones in 2002. This instrument evaluates five major personality factors and offers an abridged version for measuring the following dimensions: Neuroticism, Extraversion, Openness to experience, Agreeableness, and Conscientiousness or Responsibility. The test is composed of 60 items with response options ranging from A (Strongly Disagree) to E (Strongly Agree). Reliability of internal consistency in the development and validation of the questionnaire is shown by values ranging between .86 and .95 , with test-retest reliability values ranging between .70 and .92 for the Spanish sample, in addition to factorial validity. 
The Trait Meta-Mood Scale-24 (TMMS-24) is a version of TMMS-48 (developed by Salovey and Mayer) adapted and shortened by Fernández-Berrocal, Extremera and Ramos (2004). This self-report measure assesses three key dimensions of emotional intelligence: emotional attention, emotional clarity, and repair/emotional control. The subjects were asked to evaluate the degree to which they agreed with each item on a Likert-type scale of 5 points $(1=$ Strongly Disagree, 5 $=$ Strongly Agree). After having been shortened, the scale showed increased reliability in all of its factors: Attention (.90), Clarity (.90), and Repair/Control (.86).

The Self Report Inventory (SSRI) from Schutte et al. (1998) adapted by Chico (1999), who evaluated the scale's psychometric properties and concluded that these were adequate. This Likert-type scale ( $1=$ Strongly Disagree; $5=$ Strongly Agree) is composed of 33 items, 13 of which refer to the appraisal and expression of emotions, 10 to the regulation of emotions, and the remaining 10 to the utilisation of emotional information. Therefore, this test includes the three factors proposed by Mayer and Salovey in 1990.

For the variable of academic performance, average grades obtained during university studies expressed in a scale of 1 to 10 points were used. The University of Alicante provided information these grades upon prior consent granted by the participants and authorisation given by the university academic authority.

In order to gather information on employment, the participants completed a questionnaire on whether they were employed or unemployed and the number of months they had been employed since graduation.

\section{Procedure}

Data collection was executed in two phases. The first phase was carried out when the participants were in their final year of university studies, and the second phase was conducted two years after the participants had completed their studies.

During the first phase, participants were selected using a stratified random sampling process proportional to the number of students enrolled in the aforementioned degree courses. The study was carried out with a representative sample of students in their final year of their degree. Upon completion of the selection procedure, the chosen scales were applied. The scales were distributed in class during the academic year, according to the instructions given in their corresponding 
manuals. Students were given approximately two hours to complete the scales during a single session. Scale administration was carried out using the following procedure: first, a presentation letter was distributed and an oral presentation of research objectives was given. The participants gave their written consent and committed to facilitating the information required for the study. Then, the different questionnaires were administered in the following order: Cattell test of $g$ factor, NEO-FFI, TMMS-24 and SSRI. The participants' grades were obtained once the academic year had finished.

During the second phase, information on participants' employment was collected via a questionnaire sent both by email and by post.

\section{Design and data analysis}

Correlation and multiple regression techniques were used to analyse the data, using the hierarchical regression procedure.

A series of multiple regression analyses were performed, using the number of months employed as a criterion in order to ascertain the predictive value of the variables concerning labour integration considered in the project (analysed in accordance with data regarding the number of months employed since graduation). In this type of analysis, the variables that are first entered into the equation are attributed with all of the variance. Thus, the variables that are entered first act as covariants of those which are subsequently included. In this way, the effect of the first on the second may be partitioned. The only variable that can contribute on its own to the explanation of the criterion is the last one to be introduced. Thus, an overestimation of the predictive value of variables entering the equation first is obtained, which is why the decision to initially introduce certain variables before others was made on a theoretical basis.

Apart from the possibility of examining the unique contribution of the variables or groups of variables subsequently introduced into the equation through a hierarchical regression analysis, it is possible to detect whether there is a significant increase in the explained variance of the criterion each time a variable, or block of variables, is inserted into the equation.

Data analysis was completed using the SPSS Version 18 statistical package licensed to the University of Alicante. 


\section{Results}

\section{Results of the correlation analysis}

Table 1 shows existing correlations between the different variables included in the study.

As expected, emotional factors correlate with one another. The neuroticism personality factor also had a significantly negative correlation with the regulation of emotions $(r=-.435)$. Likewise, the extraversion personality factor also had a very significant correlation with the emotional factors of emotional clarity $(\mathrm{r}=.432)$, emotional control $(\mathrm{r}=.366)$, expression of emotions $(\mathrm{r}=.598)$, regulation of emotions $(\mathrm{r}$ $=.668)$ and use of emotions $(r=.416)$. There are also very significant correlations between the responsibility personality factor and the use of emotions $(\mathrm{r}=.419)$.

Finally, it is worth highlighting that variables having a significant correlation with the variable of labour integration are the neuroticism personality factor $(r=.296)$, openness to experience $(r=.283)$, and conscientiousness/responsibility $(\mathrm{r}=.383)$, as well as the factor attention to emotions $(\mathrm{r}=.349)$. 
Table 1. Intercorrelations between variables

\begin{tabular}{|c|c|c|c|c|c|c|c|c|c|c|c|c|c|c|c|c|c|}
\hline 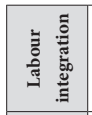 & & & & & & & & & & & & & & & $\underset{-1}{\circ}$ & 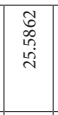 & 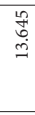 \\
\hline 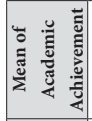 & & & & & & & & & & & & & & $\underset{-}{8}$ & $\stackrel{\infty}{~}$ & 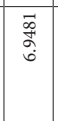 & $\stackrel{\text { }}{\stackrel{q}{f}}$ \\
\hline 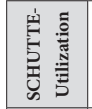 & & & & & & & & & & & & & $\overbrace{-1}^{\circ}$ & $\begin{array}{l}\stackrel{\infty}{\infty} \\
\stackrel{0}{1}\end{array}$ & $\begin{array}{l}8 \\
\text { I }\end{array}$ & 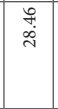 & 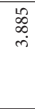 \\
\hline 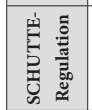 & & & & & & & & & & & & $\overbrace{-}^{\circ}$ & : & 孚 & $\stackrel{\circ}{7}$ & $\begin{array}{l}\overrightarrow{\tilde{F}} \\
\vec{F}\end{array}$ & 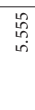 \\
\hline 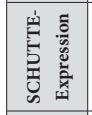 & & & & & & & & & & & $\overbrace{-1}^{\circ}$ & $\stackrel{+}{*}$ & $\vec{s}$ & $\frac{a}{0}$ & 象 & $\begin{array}{l}\vec{R} \\
\infty \\
n \\
n\end{array}$ & $\begin{array}{l}\text { वे } \\
\text { in }\end{array}$ \\
\hline 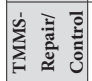 & & & & & & & & & & $\overbrace{-i}$ & స్ & tr & 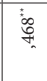 & $\vec{\sigma}$ & $\stackrel{\infty}{\stackrel{\infty}{1}}$ & 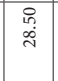 & : \\
\hline 离量 & & & & & & & & & $\overbrace{-}$ & 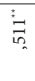 & 总 & $\begin{array}{l}\infty \\
:\end{array}$ & 角 & \pm & $\stackrel{\circ}{\circ}$ & 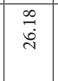 & 角 \\
\hline 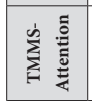 & & 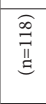 & & & & & & & 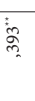 & $\stackrel{\circlearrowright}{\sim}$ & 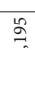 & $\stackrel{\infty}{\Rightarrow}$ & $\vec{\partial}$ & $\stackrel{0}{0}$ & of & 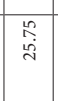 & Sू \\
\hline 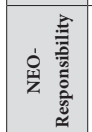 & & & & & & : & & & 表 & $\stackrel{m}{9}$ & iู & 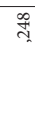 & $\%$ & $\frac{g}{i}$ & $\infty_{\infty}^{\infty}$ & $\begin{array}{l}\infty \\
\stackrel{\infty}{q} \\
\dot{q}\end{array}$ & $\begin{array}{l}\infty \\
\infty \\
\infty \\
i\end{array}$ \\
\hline 它 & & & & & $\overbrace{-}^{\circ}$ & 告 & & & $\stackrel{n}{n}$ & 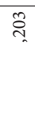 & స్లે & $\stackrel{\circ}{\circ}$ & $\stackrel{m}{\vec{d}}$ & $\stackrel{8}{\circ}$ & $\begin{array}{l}0 \\
0 \\
0\end{array}$ & $\vec{F}$ & 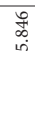 \\
\hline 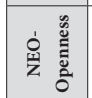 & & & & $\underset{-1}{0}$ & 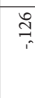 & 왐 & & & 商 & ํำ & $\stackrel{\circ}{\stackrel{\circ}{\prime}}$ & 茪 & 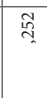 & 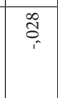 & 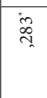 & 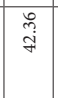 & 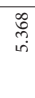 \\
\hline 㝗竞 & & & $\mathbb{- i}_{-1}$ & 资 & $\stackrel{\circ}{\circ}$ & ন্ & & & $\stackrel{\bar{q}}{\tilde{\sigma}}$ & 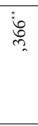 & 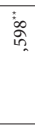 & 总 & 6 & 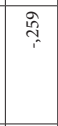 & $\tilde{\tilde{g}}$ & 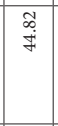 & $\stackrel{\sim}{\pi}$ \\
\hline 竞 & & $\overbrace{-1}^{\circ}$ & $\frac{F}{i}$ & సั. & $\stackrel{\circ}{7}$ & ฮิ & & & $\stackrel{7}{\overparen{7}}$ & ๙ิ & iู & 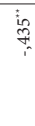 & 落 & to & ๙ุ & $\begin{array}{l}\vec{a} \\
\dot{m} \\
\dot{m}\end{array}$ & 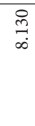 \\
\hline 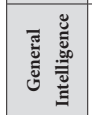 & $\stackrel{\circ}{\circ}$ & 品 & $\approx$ & $\stackrel{m}{\stackrel{m}{r}}$ & 귝 & $\stackrel{\infty}{9}$ & & & 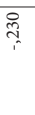 & 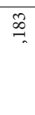 & $\stackrel{\infty}{\sim}$ & $\overrightarrow{\widetilde{i}}$ & : & $\stackrel{\circ}{\circ}$ & 雚 & 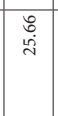 & $\underset{\text { ò }}{+}$ \\
\hline & 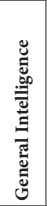 & 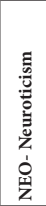 & 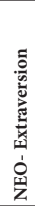 & 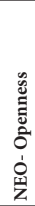 & 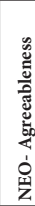 & 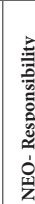 & & & 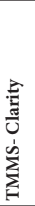 & 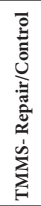 & 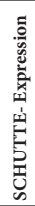 & 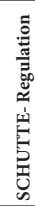 & 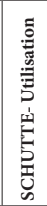 & 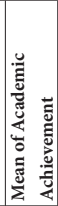 & 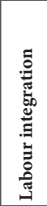 & \begin{tabular}{l|l}
5 \\
$\frac{5}{2}$
\end{tabular} & कि \\
\hline
\end{tabular}

${ }^{*} \mathrm{p}<.05$ two-tailed

${ }^{* *} \mathrm{p}<.005$ two-tailed 


\section{Results of the hierarchical multiple regression analysis}

First, after evaluating the suppositions of the multiple regression analysis we may conclude that our data adapt to the suppositions of the multiple regression analysis. They satisfy the requirements of normality, linearity and homogeneity of variance, as well as independence of errors.

The supposition of normality underlying the multivariate distribution of the variables was verified when comparing the distribution observed of the residuals with that expected under the supposition of normality. The result was that the standardised scores of the residuals were distributed along a straight diagonal line, indicative of the normality of the joint distribution of the variables.

The suppositions of linearity and homogeneity of variance were verified by observing the scatter diagram in which the residuals were projected against the predicted values, which showed the residuals distributed at random around the centre of the diagram. Furthermore, no value is positioned outside the expected results (outlier).

The Durbin-Watson test is used to test the supposition of error independence. The value of the Durbin-Watson statistical D for our data was of 2.368 , whereby we consider that this supposition is also verified.

Table 2 shows the results of the hierarchical regression analysis in which blocks of variables relating to intelligence, personality, emotional intelligence and academic achievement, as well as the variable relating to labour integration (months employed) as criterion, are introduced successively. 
Table 2. Summary of the hierarchical regression analysis for variables predictive of labour integration $(\mathrm{N}=50)$

\begin{tabular}{|c|c|c|c|c|}
\hline \multicolumn{2}{|c|}{ Variables } & \multirow{2}{*}{$\begin{array}{c}\text { B } \\
.191\end{array}$} & \multirow{2}{*}{$\begin{array}{c}\text { Std. Error } \\
.321\end{array}$} & \multirow{2}{*}{$\begin{array}{c}\beta \\
.086\end{array}$} \\
\hline Step 1 & General Intelligence & & & \\
\hline \multirow{6}{*}{ Step 2} & General Intelligence & .093 & .303 & .042 \\
\hline & NEO- Neuroticism & .178 & .147 & .160 \\
\hline & NEO- Extraversion & -.132 & .197 & -.093 \\
\hline & NEO- Openness & .430 & .227 & .249 \\
\hline & NEO- Agreeableness & -.178 & .213 & -.112 \\
\hline & $\begin{array}{l}\text { NEO- Conscientiousness/ } \\
\text { Responsibility }\end{array}$ & .772 & .201 & $.502^{\star *}$ \\
\hline \multirow{12}{*}{ Step 3} & General Intelligence & -.433 & .537 & -.194 \\
\hline & NEO- Neuroticism & -.289 & .215 & -.260 \\
\hline & NEO- Extraversion & .106 & .304 & .075 \\
\hline & NEO- Openness & .380 & .265 & .220 \\
\hline & NEO- Agreeableness & -.498 & .258 & -.314 \\
\hline & NEO- Responsibility & .869 & .281 & $.565^{\star *}$ \\
\hline & TMMS- Attention & .729 & .258 & $.463^{\star *}$ \\
\hline & TMMS- Clarity & -.150 & .266 & -.105 \\
\hline & TMMS- Repair/Control & .145 & .406 & .092 \\
\hline & SCHUTTE- Expression & .299 & .314 & .174 \\
\hline & SCHUTTE- Regulation & $-1,317$ & .551 & $-.752^{*}$ \\
\hline & SCHUTTE- Utilisation & 1.071 & .602 & .437 \\
\hline \multirow{13}{*}{ Step 4} & General Intelligence & -.399 & .465 & -.179 \\
\hline & NEO- Neuroticism & -.309 & .187 & -.277 \\
\hline & NEO- Extraversion & .496 & .284 & .349 \\
\hline & NEO- Openness & .263 & .232 & .152 \\
\hline & NEO- Agreeableness & -.256 & .233 & -.162 \\
\hline & NEO- Responsibility & .629 & .252 & $.409^{*}$ \\
\hline & TMMS- Attention & .617 & .226 & $.392^{*}$ \\
\hline & TMMS- Clarity & -.433 & .243 & -.304 \\
\hline & TMMS- Repair/Control & -.093 & .357 & -.059 \\
\hline & SCHUTTE- Expression & .407 & .274 & .237 \\
\hline & SCHUTTE- Regulation & $-1,566$ & .482 & $-.894^{\star \star}$ \\
\hline & SCHUTTE- Utilisation & 1,785 & .556 & $.728^{\star *}$ \\
\hline & Mean of Academic Achievement & 2.741 & .749 & $.465^{\star *}$ \\
\hline
\end{tabular}

Note. $\mathrm{R}^{2}=.007$ step $1 ; \Delta \mathrm{R}^{2}=.339$ step $2 ; \Delta \mathrm{R}^{2}=.160$ step $3 ; \Delta \mathrm{R}^{2}=.140$ step $4(\mathrm{ps}<.002)$

$* \mathrm{p}<.05$

$* * \mathrm{p}<.005$ 
Firstly, the block of intellectual skills is entered into the equation. The contribution of this block is not significant $(\mathrm{F}=.357, \mathrm{p}=$ .553). The inclusion of the second block of variables relative to the personality trait presuppose a significant increase in the explained variance $(F=3.793, p=.004)$. When the third step includes variables relating to emotional intelligence a significant increase of the explained variance is obtained $(\mathrm{F}=3.158, \mathrm{p}=.004)$. In the last step, when the variable of academic achievement is included a significant increase of the explained variance is, in fact, obtained $(\mathrm{F}=4.922, \mathrm{p}=.000)$.

Therefore, once the effect of the previously introduced variables has been controlled, the blocks of variables that prove to contribute most significantly to the explanation of learning processes are those measurements relating to personality traits, emotional intelligence and academic achievement.

The variables that specifically and significantly contribute to explaining the criterion are responsibility $(\beta=.409, \mathrm{p}=.017)$, emotional attention $(\beta=.392, p=.010)$, regulation of emotions $(\beta=-.894$, $\mathrm{p}=.002)$ negatively correlated, the use of emotions $(\beta=.728, \mathrm{p}=$ $.003)$ and average grades obtained during university studies $(\beta=.465$, $\mathrm{p}=.001)$.

Taken as a whole, these variables contribute significantly to explaining labour integration and account for $64 \%$ of the variance in the criteria.

\section{Discussion}

Given these results, variables that are significantly related to or contribute to explaining labour integration - time in months of employment - of university graduates from Departments of Education are centred upon personality-related aspects, emotional intelligence and academic performance, particularly the factors of responsibility (NEO), attention to emotions (TMMS), regulation of emotions (SSRI) negatively correlated, use of emotions (SSRI) and academic performance.

The highest percentage of the explained variance of labour integration is attributed to personal and emotional variables (50\%), while general intelligence explains an insignificant percentage (.07\%) and acquired knowledge - mean academic performance - does so for $14 \%$.

Explained more clearly, university graduates in the field of education who find work earlier, i.e., have been employed longer since 
graduation, have a greater sense of responsibility, pay more attention to their emotions and, despite having less control over them, they put their emotions to better use. Finally, their academic performance is higher.

Although these results reveal that professional achievement (labour integration in this case) of teachers is partially predicted or explained by technical competencies as evidenced by academic performance, greater explanatory power is attributed to emotional competencies, as revealed in other studies (Goleman, 1998; Hettich, 2000). However, contrary to the findings of different authors (Schmidt \& Hunter, 1998), other factors, such as general intelligence, fail to have a significant effect.

Therefore, it seems clear that several personality-related factors and emotional intelligence are linked to professional achievement - or with an aspect of this, such as labour integration - of teachers. This provides another reason, along with the existing relationship between socioemotional competencies and efficacy in teaching (Chan, 2008; Di Fabio \& Pazazzeschi, 2008; Jennings \& Greenberg, 2009; Sutton \& Wheatly, 2003), for teacher training institutions to foster the development of personal and socioemotional competencies (Weare \& Grey, 2003).

Research is being carried out in the European Higher Education Area for the purpose of identifying key competencies for university graduates as well as the role played by these competencies in labour integration. The implementation of the Bologna Declaration of 1999 for creating the European Higher Education Area resulted in specific proposals for competency-based design and development of educational syllabi and university curricula, such as the Tuning Educational Structures in Europe project (González \& Wagenaar, 2003), which proposes a series of generic competencies, mostly overlapping with the personal and socioemotional competencies studied under the umbrella term of socioemotional intelligence. However, the project's conclusions leave unanswered questions as to "whether these competencies are shared or specific, how they are to be identified, how to integrate them within university curricula or foster their development in higher education" (Gonzalez \& Wagenaar, 2003, p. 40). One of the proposals presented by companies in order to transfer these results to training programmes is to integrate specific training on professional competencies and skills within courses included in university curricula. Companies and, in general, both public and private organisations, demand highly qualified professionals trained in all aspects of the individual, and the 
university must be able to satisfy this need (Campos, 2008).

Another proposal centred on generic competencies is included in the 2005 DeSeCo (Definition and Selection of Competencies) Project Report, a project sponsored by the Organisation for Economic Co-operation and Development (OECD, 2005). Three main types of competencies related to the following are considered: a) the use of new technologies, b) interpersonal skills and the ability to work as a member of a group, and c) the capacity to work independently.

In 2005, the European Parliament approved a recommendation for Member States to develop a series of generic competencies in the European Higher Education Area (Education Council, 2006). These eight key competencies are considered to be essential skills, knowledge and attitudes that every European should have in order to prosper in a knowledge-based society. Of the eight key competencies, four are personal and/or socioemotional in nature: a) learning to learn; b) interpersonal, intercultural and social competencies, and civic competence; c) entrepreneurship; and d) cultural expression.

In addition, within the European Union $6^{\text {th }}$ Framework Programme (FP6), the main objective of a Spanish research project entitled "The Flexible Professional in the Knowledge Society: New Demands on Higher Education in Europe" or REFLEX (ANECA, 2007), is to analyse and diagnose the labour integration of university graduates. The project's goal is to respond to a number of general questions concerning: the competencies required of university graduates for their integration into the knowledge society; the role universities play in developing these competencies; the degree to which graduate expectations are fulfilled regarding employment and ways to resolve the imbalance between graduate expectations and the characteristics of their jobs.

Therefore, it is necessary to make progress towards new proposals for integrating and developing these competencies in the higher education curricula, such as those put forward in the book edited by Fallows and Steven (2000), and other perspectives from the United States and Canada presented by Boyatzis, Cowen, and Kolb (1995) and Boyatzis, Wheeler and Wright (2001). Moreover, some current study plans and university curricula implement these competencies, such as several Australian universities (Nunan, George \& McCausland, 2000), the American Harvard Business School (Jaeger, 2003; Prahalad \& Hamel, 1990) or the English Sheffield Hallam University, to name a few.

Despite the importance given to emotional intelligence in the 
educational context for developing the professional activity of teachers, very few syllabi actually focus on teacher training. Numerous researchers have pointed out the need for even basic teacher training to include the development of emotional intelligence as part of the generic competencies proposed by the European Higher Education Area (Bisquerra, 2005; Bueno, Teruel \& Valero, 2005; Extremera \& Fernández-Berrocal, 2004; Pesquero, Sánchez, González \& Martín, 2008; Teruel, 2000). Despite clear evidence, in some cases, that training novice teachers in emotional competencies has proven to be effective not only in increasing their own emotional competencies but also for predicting a smooth transition from their role as a student to that of a professional teacher (Byron, 2001), specific proposals are still needed as to how to include these competencies in teacher education. Pug's (2008) study conducted in a primary school concludes that higher education programmes and partner schools would benefit from time, curriculum provision and government agency support to recognise, reflect upon and develop emotional intelligence in teaching.

Specific emotional knowledge and skills should become part of the teacher education curriculum to better prepare pre-service teachers in the affective domain (Kassem, 2002). Cohen (2001) suggests that teacher education program need address: 1. the role of emotion in learning and in creating; 2. emotional "decoding" skills; and 3. ways of use decoding emotions to solve real-life, social-emotional problems. Methods for implementing socio-emotional curriculum in teacher education fall along a continuum. Curriculum changes could be implemented by the addition of standalone courses on socio-emotional content or by the integration of emotional components into the current curriculum, through the use of such common tools as case studies and cooperative learning. Cohen's (2001) compilation of practices in the United States provides research evidence regarding certain successful methods.

Some recommendations for developing these competencies in higher educational programmes are referenced to competencies proposed in the Tuning project (González \& Wagenaar, 2003), which to a great extent have been adopted in the European Higher Education Area, most of which are upheld by the DeSeCo Project (OECD, 2005) as well as the European Education Council (2006). For example, academics could introduce teamwork (Koman \& Wolff, 2008) to help students develop interpersonal relationships with other group members, along with self-awareness and their capacity to empathise with others. 
The ability for criticism and self-criticism may be developed through immediate and accurate feedback given by the teacher on one's projects (homework, examinations, etc.). The skill for working autonomously may be fostered through independent tasks that require informational searches while laying the foundations for lifelong learning. Practicums outside of the academic realm, carried out in businesses or organisations - such as those which students complete in educational centres - may strengthen the integration of knowledge, the application of knowledge in practice, interpersonal relations, initiative, assertiveness, adaptation to new situations, etc. The ability to deal with differences and contradictions is found in many of the educational sector's lists of key competencies. A complex world demands that we do not necessarily dash towards a single answer or an either/or solution, but rather favour creativity in managing tensions inherent to the diversity of circumstances.

Finally, our study generated some unexpected results that deserve more attention: firstly, the negative correlation that exists between emotional regulation and employability, which is difficult to explain in this context, unless it is taken to mean that emotional regulation implies the existence of negative emotions which might not be present in the most employable graduates. Meanwhile, the use of one's own emotions is seen to be positive; secondly, the low correlation of academic achievement with employability that may be explained by the fact that technical knowledge - represented by academic performance - plays a lesser role during initial employment when compared with professional teaching experience; and thirdly, the no correlation of intelligence with academic achievement, also detected in studies on engineering graduates (Pérez \& Castejón, 2007), that may be explained by the effect of the restricted range of intellectual capacity of a selected sample of university graduates, where levels are expected to be mid to high. Alternately, this may also be attributed to the inability of academic performance-related criteria to reflect deeper aspects of thinking or intellectual capacity, at least within the scope of university teacher training, which would be even more problematic.

\section{Acknowledgements}

This research was supported by the Spanish Ministry for Science and Innovation (Project PSI2009-12696) titled: Intellectual, Personal and Socioemotional Competencies in the Labour integration of University Graduates. 


\section{References}

Agencia Nacional de Evaluación de la Calidad y Acreditación (ANECA, 2007). Project

Reflex. Executive Report. June 2007. Spanish Ministry of Education.

Amelang, M., \& Steinmayr (2006). Is there a validity increment for tests of emotional intelligence in explaining the variance of performance criteria? Intelligence, 34, 459-468. Ayers, D., \& Stone, B. (1999). Extension organization of the future: Linking emotional intelligence and core competencies. Journal of Extension, 37(6). Retreived from http://joe. org/joe/1999december/iw4.html.

Barchard, K. (2003). Does emotional intelligence assist in the prediction of academic success? Educational and Psychological Measurement, 63(5), 840-858.

Bar-On, R. (200o). Emotional and social intelligence: Insights from the Emotional Quotient Inventory (EQ-i). In R. Bar-On and J. D. A. Parker (Eds.), The handbook of emotional intelligence: Theory, development, assessment, and application at home, school, and in the workplace (pp. 363-387). San Francisco, CA: Jossey-Bass Inc.

Bastian, V.A., Burns, N. R., \& Nettelbeck, T. (2005). Emotional intelligence predicts life skills, but not as well as personality and cognitive abilities. Personality and Individual Differences, $39,1135-1145$.

Bisquerra, R. (2005). La educación emocional en la formación del profesorado [Education on emotions in teacher training]. Revista Interuniversitaria de Formación del Profesorado, 19(3), 95-114.

Boyatzis, R. E. (2008). Competencies in the 21st century. Journal of Management Development, $27(1)$, 5-12.

Boyatzis, R. E. (1999). Self-directed change and learning as a necessary meta-competency for success and effectiveness in the $21^{\text {st }}$ century. In R. Sims \& J. G. Veres (Eds.), Keys to employee success in the coming decades (pp. 15-32). Westport: Greenwood. Boyatzis, R. E., Cowen, S. S., \& Kolb, D. A. (Eds.), (1995). Innovation in professional education: Steps on a journey from teaching to learning. San Francisco: Jossey-Bass. Boyatzis, R., Goleman, D., \& Rhee, K. (200o). Clustering competence in emotional intelligence. Insights from the emotional competence inventory (ECI). In R. Bar-On \& J. D. A. Parker (Eds.), Handbook of emotional intelligence (pp. 343-367). San Francisco: Jossey-Bass.

Boyatzis, R. E., Wheeler, J., \& Wright, R. (2001). Competency development in graduate education: A longitudinal perspective. In Proceedings of the First World Conference on SelfDirected Learning. Montreal: GIRAT.

Brackett, M., \& Mayer, J. D. (2003). Convergent, discriminant, and incremental validity of competing measures of emotional intelligence. Personality and Social Psychology Bulletin, $29(9), 1147-1158$.

Bueno, C., Teruel, M. P., \& Valero, A. (2005). La inteligencia emocional en alumnos de Magisterio: La percepción y comprensión de los sentimientos y las emociones [Emotional intelligence in students of teaching. The perception and comprehension of feelings and 
emotions]. Revista Interuniversitaria de Formación del Profesorado, 19(3), 169-194. Campos, M. C. (2008). Los egresados y su situación laboral ¿estudias o trabajas [Graduates and their employment status: Do you work or study?]. Revista Fuentes, 8, 1-11. Cattell, R. B. \& Cattell, A. K. (1963). Test of g: Culture fair, Scale (Champaign, III: Institute for Personality and Ability Testing (Spanish adaptation by TEA Editions, 2002).

Chan, D. W. (2006). Emotional Intelligence components and burnout among Chinese secondary school teachers in Hong Kong. Teaching and Teacher Education, 22(8), 10421054.

Chan, D. W. (2008). Emotional intelligence, self-efficacy, and coping among Chinese prospective and in-service teachers in Hong Kong. Educational Psychology, 28(4), 397-408. Cherniss, C. (2000). Social and Emotional Competence in the workplace. In R. Bar-On \& J. D. Parker (Eds.), The handbook of emotional intelligence (pp.453-458). San Francisco: Jossey-Bass.

Chico, E. (1999). Evaluación psicométrica de una escala de inteligencia emocional [Psychometric evaluation of an emotional intelligence scale]. Boletín de Psicología, 62, 65-78.

Cohen, J. (Ed.) (2001). Caring classrooms/intelligent schools: the social emotional education of young children. New Tork: Teachers College Press.

Costa, P. T., Jr., \& McCrae, R. R. (1992). NEO PI-R, Professional Manual. Revised NEO Personality Inventory (NEO PI-R) and NEO Five Factor Inventory (NEO-FFI). Odessa, FL: Psychological Assessment Resources.

Coté, S., \& Miners, CTH. (2006). Emotional intelligence, cognitive intelligence and job performance. Administration Science Quarterly, 51, 1-28.

Davies, M., Stankov, L., \& Roberts, R. D. (1998). Emotional intelligence. In: search of an elusive construct. Journal of Personality and Social Psychology, 75, 989-1015.

Di Fabio, A. \& Palazzeschi, L. (2008). Emotional intelligence and self-efficacy in a sample of Italian high school teachers. Social Behavior and Personality, 36(3), 315-325.

Dulewicz, V., Higgs, M., \& Slaski, M. (2003). Measuring emotional intelligence: content, construct and criterion-related validity. Journal of Managerial Psychology, 18(5), 405-420.

Echeverría, B. (2002). Gestión de la competencia de acción profesional [Managing competencies in professional practice]. Revista de Investigación Educativa, 20(1), 7-42. Education Council (2006). Recommendation of the European Parliament and the Council of 18 December 2006 on key competencies for lifelong learning. Brussels: Official Journal of the European Union, 30. 12. 2006.

Extremera, N., \& Fernández-Berrocal, P. (2004). La importancia de desarrollar la inteligencia emocional en el profesorado [The importance of developing emotional intelligence in teachers]. Revista Iberoamericana de Educación, 33(8). Retreived form http://www.campus-oei.org/revista/deloslectores/759Extremera.PDF. Fallows, S., \& Steven, C. (Eds.) (2000). Integrating key skills in higher education: employability, transferable skills and learning for life. London: Kogan Page. 
Fernández-Berrocal, P., Extremera, N., \& Ramos, N. (2004). Validity and reliability of the Spanish modified version of the Trait Meta-Mood Scale (TMMS-24). Psychological Report, 94, 751-755.

García-Aracil, A., \& Van der Velden, R. (2008). Competencies for young European higher education graduates: labour market mismatches and their payoffs. Higher Education, 55(2), 219-239.

Goleman, D. (1995). Emotional Intelligence. New York: Bantam Books, Inc.

Goleman, D. (1998). Working with emotional intelligence. Santa Ana: Books on Tape, Inc.

Goleman, D. (2001). Emotional intelligence perspectives on a theory of performance. In

C. Cherniss, \& D. Goleman (Eds.), The emotionally intelligent workplace (pp. 27-44). San

Francisco: Jossey-Bass.

González, J., \& Wagenaar, R. (2003). Tuning Educational Structures in Europe. Final

Report. Phase One. Bilbao: Universidad de Deusto.

Gottfredson, L. S. (2003). Jobs and Life. In H. Nyborg (Ed.), The Scientific Study of General Intelligence (pp. 293-342). Oxford: Elsevier Science/Pergamon.

Hedlund, J., \& Sternberg, RJ. (200o). Too many intelligences? Integrating social, emotional and practical intelligence. In R. Bar-On, \& J. D. A. Parker (Eds.), The handbook of emotional intelligence (pp. 136-168). San Francisco: Jorsey-Bass.

Hettich, P. (2000). Transition processes from college to career. Washington: American Psychological Association.

Jaeger, A. (2003). Job competencies and the curriculum: An inquiry into emotional intelligence in graduate professional education. Research in Higher Education, 44(6), 615-639.

Jennings, P. A. \& Greenberg, M. T. (2009). The Prosocial Classroom: Teacher Social and Emotional Competence in Relation to Student and Classroom Outcomes. Review of Educational Research, 79(1), 491-525.

Kassem, C. L (2002). Developing the teaching professional: what teacher educators need to know about emotions. Teacher Development, 6(3), 363-372.

Koman, E. S. \& Wolff, S. B. (2008). Emotional intelligence competencies in the team and team leader: A multi-level examination of the impact of emotional intelligence on team performance. Journal of Management Development, 27(1), 55-75.

Landa, J. M. A., Lopez-Zafra, E., Martinez, R., \& Pulido, M. (2006). Perceived emotional intelligence and life satisfaction among university teachers. Psicothema, 18, 152-157. Lopes, P. N., Coté, S., Grewal, D., Kadis, J., Gall, M. \& Slovey, P. (2006). Emotional intelligence and positive work outcomes. Psicothema, 18(Suppl.), 132-138.

Matthews, G., Zeidner, M., \& Roberts, R. (2003). Emotional intelligence: Science and Myth. Cambridge: MIT Press.

Mayer, J., Caruso, DR., \& Salovey, P. (2000). Emotional intelligence meets traditional standards for an intelligence. Intelligence, 27(4), 267-298.

Mayer, J., Caruso, DR., Salovey, P., \& Sitarenios, G. (2003). Measuring emotional 
intelligence with the MSCEIT V2.o. Emotion, 3(1), 97-105.

Mayer, J. D., Roberts, R. D., \& Barsade, S. G. (2008). Human Abilities: Emotional

Intelligence. Annual Review of Psychology, 59, 507-536.

Mayer, J., Salovey, P., \& Caruso, D. (2000). Emotional intelligence as Zeitgeist, as personality, and as mental ability. In R. J. Sternberg (Ed.), Handbook of emotional intelligence (pp. 92-117). San Francisco: Jossey Bass.

Mora, J. (1997), Empleo y cualificación tras la educación postobligatoria [Employment and qualifications after compulsory education]. Tribuna de Economía, 764.

Nunan, T., George, R., \& McCausland, H. (2000). Implementing graduate skills at an Australian university. In S. Fallows \& C. Steven (Eds.), Integrating key skills in higher education: employability, transferable skills and learning for life (pp. 183-20o). London:

Kogan Page.

Organisation for Economic Co-operation and Development (OECD). (2005). The

definition and selection of key competencies. Executive Summary.Retreived form http://

www.oecd.org/dataoecd/47/61/35070367.pdf.

Palací, F. J., \& Moriano, J. A. (Coords.) (2002). El Nuevo Mercado laboral: estrategias de inserción y desarrollo profesional [The new labour market: strategies for insertion and professional development]. Madrid: UNED.

Palací, F. J. \& Topa, G. (Coords.) (2002). La persona en la empresa: iniciativas de integración y desarrollo [The individual in the company: initiatives for integration and development]. Madrid: UNED.

Palomera, R., Fernández-Berrocal, P., \& Brackett, M. A. (2008). La inteligencia emocional como una competencia básica en la formación inicial de los docentes: algunas evidencias [Emotional intelligence as a basic competency in initial training for teachers: some evidence]. Revista Electrónica de Investigación Psicoeducativa, 15(6-2), 437-454.

Pérez, N., \& Castejón, J. L. (2007). La inteligencia emocional como predictor del rendimiento académico en estudiantes universitarios [Emotional intelligence as a predictor of academic performance in university students]. Ansiedad y Estrés, 13(1), 119129.

Pesquero, E., Sánchez, M. E., González, M., \& Martín, R. (2008). Las competencias profesionales de los maestros de Primaria [Professional competencies of primary school teachers]. Revista Española de Pedagogía, 241, 447-466.

Petrides, K. V., \& Furnham, A. (2003). Trait emotional intelligence: Behavioral validation in two studies of emotion recognition and reactivity to mood induction. European Journal of Personality, 17, 39-57.

Planas et al. (2000). Marché de la Compétence et dynamiques d’ajustement. Les Cahiers du LIRHE, 6.

Prahalad, C. K., \& Hamel, G. (1990). The core competence of the Corporation. Harvard Business Review, May, 79-92.

Pug, E. V. (2008). Recognising emotional intelligence in professional standards for 
teaching. Practitioner Research in Higher Education, 2(1), 3-12.

Rozell, E., Pettijohn, Ch. E., \& Parker, R. S. (2002). An empirical evaluation of emotional intelligence: The impact on management development. Journal of Management Development, 21(4), 272-289.

Salovey, P., \& Mayer, J. D. (1990). Emotional intelligence. Imagination, Cognition, and Personality, 9, 185-211.

Schmidt, F. L., \& Hunter, J. E. (1998). The validity and utility of selection methods in personal psychology: Practical and theoretical implications of 85 years of research findings. Psychological Bulletin, 124, 262-274.

Sheffield Hallam University. Key Skills On-line [www document]. Retreived from http:// www.shu.ac.uk/keytokey/shucontens.htm.

Schutte, N. S., Malouff, J. M., Hall, L. E., Haggerty, D. J., Cooper, J. T., Golden, C. J., et al. (1998). Development and validation of a measure of emotional intelligence. Personality and Individual Differences, 25, 167-177.

Sternberg, R. J. (2003). Reply to the book review on Practical Intelligence in Everyday Life. Intelligence, 31(4), 395-408.

Sternberg, R. J., Castejón, J. L., Prieto, M. D., Hautamäki, J., \& Grigorenko, E. (2001).

Confirmatory factor analysis of the Sternberg Triarchic Abilities Test in Three International Samples: An empirical test of the Triarchic Theory. European Journal of Psychological Assessment, 17, 1-16.

Sternberg, R. J., Prieto, M. D., \& Castejón, J. L. (2000). Análisis factorial confirmatorio del Sternberg Triarchic Abilities Test (nivel H) en una muestra española: resultados preliminares [[Confirmatory factor analysis of the Sternberg Triarchic Abilities Test (level H) in a Spanish sample: preliminary results. Psicothema, 12(4), 642-647.

Sutton, R. E., \& Wheatley, K. F. (2003). Teacher's Emotions and Teaching: A review of the literature and directions for future research. Educational Psychology Review, 15(4), 327-358. Tapia, M. (2001). Measuring emotional intelligence. Psychological Reports, 88, 353-364. Teruel, M. P. (2000). La inteligencia emocional en el currículo de la formación inicial de los maestros [Emotional intelligence in the curriculum for initial teacher training]. Revista Interuniversitaria de Formación del Profesorado, 38, 141-152.

Vanderberghe, J., \& Huberman, A. M. (Eds.), (1999). Understanding and preventing teacher burnout: A sourcebook of international research and practice. Cambridge, UK: Cambridge University Press.

Van der Zee, K., Thijs, M., \& Schakel, L. (2002). The relationship of emotional intelligence with academic intelligence and the Big Five. European Journal of Personality, 16(2), 103125.

Weare, K., \& Gray, G. (2003). What works in developing children's emotional and social competence and wellbeing? Department for Education and Skills Research Report, 456. London: DfES.

Yoon, J. S. (2002). Teacher characteristics as predictors of teacher-student relationships: 
stress, negative affect, and self-efficacy. Social Behavior and Personality: An International Journal, 3o(5), 485-493.

Zeidner, M., Matthews, G., \& Roberts, R. D. (2004). Emotional intelligence in the workplace: A critical review. Applied Psychology. An International Review, 53(3), 371-399.

\section{Biographical note}

Juan-Luis Castejón is a Permanent Professor at the University of Alicante and he was a research affiliate in the Department of Psychology at Yale University. Their main research focus is on intelligence, emotional intelligence, and the psychological factors involved in learning.

RAQUel Gilar is a Ph. Doctor Assistant Profesor in the area of Educational Psychology at the University of Alicante. Their main research interest is on emotional intelligence and prosocial behaviour.

Pablo Miñano is an Associate Professor in the area of Educational Psychology at the University of Alicante (Spain). Their main research focus is on the psychological factors involved in motivation and academic achievement. 